\title{
Canton de Baume-les-Dames (Doubs)
}

\section{Claude Jacquard}

\section{OpenEdition \\ Journals}

Édition électronique

URL : http://journals.openedition.org/adlfi/8489

ISSN : 2114-0502

Éditeur

Ministère de la culture

Référence électronique

Claude Jacquard, "Canton de Baume-les-Dames (Doubs) », ADLFI. Archéologie de la France-

Informations [En ligne], Franche-Comté, mis en ligne le 01 mars 2001, consulté le 02 mai 2019. URL :

http://journals.openedition.org/adlfi/8489

Ce document a été généré automatiquement le 2 mai 2019.

(c) Ministère de la Culture et de la Communication, CNRS 


\title{
Canton de Baume-les-Dames (Doubs)
}

\author{
Claude Jacquard
}

Identifiant de l'opération archéologique : 01/26

Date de l'opération : 2000 (PR)

1 Les très nombreuses déclarations de sites témoignent de la richesse archéologique du canton de Baume-les-Dame où toutes les époques sont représentées.

2 Parallèlement aux prospections, a été effectué un sondage d'évaluation sur un des six cents tertres couvrant les monts Nord de Baume-les-Dames. Ce sondage pluriannuel portera ses fruits en 2002, sachant qu'en 2000 fut mise au jour une structure appareillée sous un tertre de $5 \mathrm{~m}^{3}$ ( $119 \mathrm{~cm} \times 148 \mathrm{~cm} \times 87 \mathrm{~cm}$ de profondeur). La poursuite du sondage permettra de répondre à diverses questions : que représentent ces tertres seulement présents sur la crête des monts, pourquoi en aussi grand nombre et à quelle époque ontils été érigés?

\section{INDEX}

Thèmes : appareil, site archéologique, tertre funéraire

Index géographique : Franche-Comté, Doubs (25), Baume-les-Dames

operation Prospection (PR) 
AUTEURS

CLAUDE JACQUARD 